\title{
DIGLOSIA
}

Terakreditasi Sinta 3 | Volume 3 | Nomor 2 | Tahun 2020| Halaman 149-162

P-ISSN 2615-725X | E-ISSN 2615-8655

http://diglosiaunmul.com/index.php/diglosia/article/view/58

\section{PENGEMBANGAN BAHAN AJAR MENULIS PUISI DENGAN PERPADUAN MODEL DEMONSTRASI DAN TEKNIK BERIUR KATA KELAS VIII SMP}

\author{
Development of Poetry Writing Teaching Materials with Combination \\ of Demonstration Models and Word Giving Techniques \\ for Eighth Graders Junior High School
}

\author{
Gigih Yudha Pratama ${ }^{1, *}$, Jafar Haruna ${ }^{2}$, M. Siddik ${ }^{3}$ \\ ${ }^{1}$ Magister Pendidikan Bahasa Indonesia, FKIP, Universitas Mulawarman \\ ${ }^{2,3}$ Universitas Mulawarman \\ Pos-el Korespondensi: gigihypbindo@gmail.com
}

\begin{abstract}
The purpose of this study (1) to test the development of poetry writing teaching materials planning with a combination of demonstration models and class VIII word giving techniques in junior high school; (2) test the feasibility of the design of poetry writing teaching materials with a combination of demonstration models and class VIII word grammar techniques; and (3) testing the effectiveness of developing poetry writing teaching materials with a combination of demonstration models and class VIII word syllabic techniques. This development research refers to the 10 stages of Borg \& Gall which are simplified into 3 stages, namely information gathering, product manufacturing planning, and product development. The results showed that the development of planning poetry writing teaching materials with a combination of demonstration models and class VIII word syllabary techniques has 14 important parts. The average score of assessment and validation by media experts, material experts, and Indonesian language teachers was obtained 4.43, this value means teaching poetry writing material with a combination of demonstration models and class VIII word giving techniques is very suitable to be used as an independent teaching material for students Class VIII Middle School. The results of the trial evaluation and validation of each aspect obtained an average score of 4.58 , this value means the teaching material of writing poetry with a combination of demonstration models and class VIII wordbearing techniques is very effective according to the responses of students of class VIII SMP.
\end{abstract}

Keywords: teaching material, poetry writing, demonstration, word giving

Abstrak: Tujuan penelitian ini (1) menguji pengembangan perencanaan bahan ajar menulis puisi dengan perpaduan model demonstrasi dan teknik beriur kata kelas VIII SMP; (2) menguji kelayakan desain bahan ajar menulis puisi dengan perpaduan model demonstrasi dan teknik beriur kata kelas VIII SMP; (3) menguji keefektifitasan pengembangan bahan ajar menulis puisi dengan perpaduan model demonstrasi dan teknik beriur kata kelas VIII SMP. Penelitian pengembangan ini mengacu pada 10 tahapan dari Borg \& Gall yang disederhanakan menjadi 3 tahapan, yaitu pengumpulan informasi, perencanaan pembuatan produk, dan pengembangan produk. Hasil penelitian menunjukkan bahwa pengembangan perencanaan bahan ajar menulis puisi dengan perpaduan model demonstrasi dan teknik beriur kata kelas VIII SMP memiliki 14 bagian penting. Skor rata-rata penilaian dan validasi oleh ahli media, ahli materi, dan guru bahasa Indonesia diperoleh nilai 4,43. Nilai ini berarti bahan ajar menulis puisi dengan perpaduan model demonstrasi dan teknik beriur kata kelas VIII SMP sangat layak digunakan sebagai bahan ajar mandiri untuk siswa Kelas VIII SMP. Hasil uji coba penilaian dan validasi tiap aspek diperoleh skor rata-rata sebesar 4,58, nilai ini berarti bahan ajar menulis puisi dengan perpaduan model demonstrasi dan teknik beriur kata kelas VIII SMP sangat efektif menurut respons siswa kelas VIII SMP.

Kata Kunci : bahan ajar, menulis puisi, demonstrasi, beriur kata 


\section{A. PENDAHULUAN}

Pendidikan dapat dimaknai sebagai suatu proses yang melewati serangkaian kegiatan. Pendidikan sebagai proses pembentukan pribadi, proses transformasi budaya, proses penyiapan warga negara dan pendidikan juga sebagai proses penyiapan tenaga kerja. Menurut Amri (2010, hal. 18), pendidikan merupakan upaya terorganisir yang memiliki makna bahwa pendidikan harus dilakukan oleh usaha sadar manusia dengan dasar dan tujuan jelas, ada tahapan dan ada komitmen bersama didalam proses pendidikan.

Pendidik (guru) harus dituntut mempunyai kompetensi (kompetensi pedagogik, kompetensi kepribadian, kompetensi sosial dan kompetensi profesi), pengembangan bahan ajar (materi ajar) dan media pembelajaran merupakan salah satu kewajiban yang harus dimiliki guru untuk mengembangkan kompetensi sebagai guru yang profesional. Hal ini sejalan dengan pendapat Suparlan (2006, hal. 42), kompetensi guru dipilih dalam tiga komponen yang saling mengait yakni pengelolaan pembelajaran, pengembangan profesi dan penguasaan akademik.

Salah satu faktor yang menentukan keberhasilan pembelajaran adalah pemilihan bahan ajar. Pemilihan bahan ajar merupakan hal penting karena dapat membantu guru melaksanakan tugas dengan baik sehingga peserta didik mampu memperoleh ilmu pengetahuan dengan berkualitas. Pemilihan bahan ajar harus memperhatikan kebutuhan peserta didik yang disesuaikan dengan lingkungan sosial dan karakteristik peserta didik. Bahan ajar sendiri diartikan sebagai seperangkat materi yang disusun secara sistematis baik tertulis maupun tidak sehingga tercipta lingkungan atau suasana yang memungkinkan siswa untuk belajar (Daryanto \& Dwicahyono, 2014, hal. 12).

Pemberlakuan Kurikulum 2013 menuntut sekolah termasuk guru untuk memiliki bahan ajar yang sesuai dengan kriteria Kurikulum 2013 sehingga pembelajaran dapat dilaksanakan secara efektif. Mata Pelajaran Bahasa Indonesia pada Kurikulum 2013 secara umum bertujuan agar peserta didik mampu menyimak, mewicara, membaca, dan menulis. Karya sastra dapat dibedakan menjadi tiga: puisi, prosa, dan drama (Munaris \& Yoga, 2017, hal. 40).

Puisi adalah karya sastra dengan bahasa yang dipadatkan, disingkat, dan diberi irama dengan bunyi yang menyatu dan pilihan kata-kata yang variatif atau imajinatif. Menulis puisi adalah keterampilan berbahasa yang diperlukan untuk meningkatkan kualitas pembelajaran. Pembelajaran menulis puisi seharusnya memungkinkan siswa untuk menyampaikan ide, gagasan, perasaan, dan pengalaman mereka secara puitis. Guru dapat membantu dan membimbing siswa untuk muncul dan mengembangkan ide dan mengaturnya menjadi puisi sederhana. Pembelajaran menulis puisi terasa sulit, disebabkan siswa tidak mampu mengimajinasikan objek atau hal-hal yang hendak disampaikan. Di samping itu, siswa juga kesulitan menempatkan ide dan pemikiran mereka ke dalam bait-bait puisi (Harper, 2007, hal. 3).

Pola pembelajaran yang benar, penggunaan model, strategi, dan metode yang tepat akan membantu siswa dalam menuangkan imajinasi mereka ke dalam puisi. Selain itu, penggunaan bahan ajar yang tepat turut membantu dan membimbing siswa dalam melaksanakan proses penulisan puisi yang tepat. Kesiapan bahan ajar termasuk faktor penentu berhasil tidaknya suatu pembelajaran (Habibi, 2019).

Bahan ajar adalah hal utama yang tidak dapat dipisahkan dari kegiatan belajar yang mampu mengantarkan siswa menguasai tujuan pembelajaran. Bahan ajar untuk menulis puisi harus mengandung tahap penulisan yang jelas dan sistematis sehingga mampu 
mengarahkan siswa untuk menuangkan imajinasi mereka ke dalam beberapa bait puisi (Sudjana, 2011, hal. 13). Hal paling penting, bahan ajar menulis puisi harus menuntut keaktifan siswa, memberikan pengajaran dan pengalaman yang menarik. Sehingga muncul kepekaan sastra pada siswa sebagai upaya menumbuhkan kebiasaan mengapresiasi sastra, khususnya apresiasi puisi (Gilbert \& Graham, 2010, hal. 71).

Bahan ajar perlu dirancang yang sesuai dengan karakteristik dan kebutuhan siswa dalam menulis puisi. Bahan ajar yang mampu mengarahkan dan membimbing siswa dalam melakukan kegiatan menulis puisi yang baik. Bahan ajar yang mengadopsi strategi atau teknik yang tepat sehingga pembelajaran terasa menyenangkan dan dapat memudahkan siswa dalam membuat puisi. Ada beberapa teknik menarik yang dapat digunakan dalam mengembangkan bahan ajar untuk menulis puisi ini, diantaranya yaitu perpaduan model demonstrasi dan teknik beriur kata.

Metode demonstrasi merupakan salah satu metode dalam pembelajaran yang pelaksanaannya dilakukan melalui penyajian bahan pelajaran dengan memperagakan atau mempertunjukkan kepada siswa suatu proses, situasi atau benda tertentu yang sedang dipelajari, baik dalam bentuk alamiah (asli) maupun dalam bentuk buatan, yang sering disertai dengan penjelasan lisan. Melalui metode demonstrasi, proses penerimaan siswa terhadap pelajaran akan lebih berkesan secara mendalam sehingga membentuk pengertian yang baik dan sempurna (Amri, 2010, hal. 16).

Penelitian terdahulu yang dilakukan Luthfira (2014) menunjukkan bahwa pengembangan bahan ajar berbasis demonstrasi memenuhi kriteria valid berdasarkan hasil uji ahli materi, ahli media, ahli mata pelajaran, hasil uji coba lapangan dan hasil belajar siswa. Hal ini menunjukkan bahwa produk yang dikembangkan memiliki kualifikasi tingkat kevalidan yang tinggi sehingga bahan ajar layak digunakan dalam pembelajaran.

Pengembangan bahan ajar menulis puisi juga dapat dipadukan dengan teknik beriur kata. Teknik beriur kata atau metode sumbang kata merupakan salah satu metode pembelajaran variatif yang dapat digunakan dalam pembelajaran menulis puisi di sekolah. Metode ini, siswa mampu berperan aktif dalam mencari pilihan kata yang nantinya akan digabungkan dengan pilihan kata temannya untuk dijadikan ide awal menulis puisi (Fauzan, 2014, hal. 19). Penelitian yang dilakukan Murniati (2010) menunjukkan bahwa keterampilan menulis puisi dengan menggunakan teknik beriur kata mengalami peningkatan dan terjadi perubahan perilaku ke arah positif.

Hasil pengamatan khususnya di SMP Muhammadiyah $6 \quad$ Samarinda menunjukkan bahwa guru mata pelajaran bahasa Indonesia telah menerapkan pembelajaran yang cukup variatif (beragam) dalam pembelajaran menulis puisi, tetapi belum maksimal. Hasil wawancara dengan beberapa pendidik Bahasa Indonesia di SMP Muhammadiyah 6 Samarinda dan beberapa pendidik sekolah lain, bahwa selama ini model pembelajaran menulis khususnya kompetensi dasar menulis puisi dengan mengidentifikasi pengalaman orang lain menggunakan metode atau model konvensional. Pendidik hanya sekedar menjelaskan tentang teori yang berhubungan dengan puisi, tidak memahamkan tentang makna dan arti sesungguhnya dari puisi. Pembelajaran yang seperti itu belum mampu membuat peserta didik tertarik dan termotivasi untuk menulis puisi yang hasilnya belum memuaskan sekedar tulisan yang tujuannya mencari nilai atau mengerjakan tugas.

Kondisi tersebut disebabkan oleh rendahnya minat menulis siswa, penguasaan kosa kata dan penggunaan 
strategi yang belum maksimal sehingga perlu adanya penanganan khusus dalam pembelajaran menulis puisi bagi siswa, khususnya pada tingkat sekolah menengah pertama atau madrasah tsanawiyah. Inti penanganan tersebut adalah diperlukannya suatu strategi pembelajaran menulis efektif dan efisien bagi siswa.

Kegiatan pembelajaran di sekolah, guru mempunyai peranan yang paling penting sehingga strategi pembelajaran dijadikan sebagai inti penanganan dalam memperbaiki pembelajaran. Seorang guru harus dapat merencanakan strategi pembelajaran yang menarik dan menerapkannya dengan baik. Dalam proses pembelajaran suasana yang dimunculkan sebaiknya menyenangkan, dan berhasil guna. Hal ini dapat dilihat dengan adanya keterlibatan secara aktif dan positif baik dari guru maupun siswa. Proses keterlibatan ini sangat bergantung pada guru dalam membuat pembelajaran, pengelolaan, dan penyampaian. Dengan kata lain, guru harus mampu mengajar secara tepat dan bervariasi sehingga pembelajaran tidak membosankan dan monoton. Sebaliknya, pembelajaran memberikesenangan, kegairahan, minat serta kebahagiaan pada siswa.

Hasil observasi dan diskusi yang dilakukan bersama kolaborator (guru), diperoleh informasi bahwa dari seluruh kelas VIII SMP Muhammadiyah 6 Samarinda, terdapat kelas yang bermasalah dalam pembelajaran Bahasa dan Sastra Indonesia. Materi pembelajaran Bahasa dan Sastra Indonesia yang dianggap sulit adalah puisi. Mulai dari menganalisis puisi, memaknai puisi, membaca puisi, apalagi menulis puisi. Puisi memiliki bentuk visual yang khas yang nenandainya sebagai karya sastra. Bahkan, dengan melihat bentuk visual tulisannya saja, walaupun belum membaca, orang sudah dapat mengenalinya sebagai puisi. Seharusnya karena bentuknya yang pendek, puisi menjadi paling populer dan mudah diajarkandi kelas dan puisi juga dapat dijadikan bahan tes siswa.

Terdapat beberapa faktor yang menyebabkan pembelajaran di kelas VIII SMP Muhammadiyah 6 Samarinda dapat dikatakan rendah yakni minat belajar siswa yang masih tergolong rendah terhadap pelajaran Bahasa Indonesia dan kurang menyukai hal-hal yang berbau sastra misalnya kegiatan menulis puisi. Sebagian besar siswa memandang pembelajaran puisi dengan sebelah mata, hanya sedikit sekali yang memiliki respon terhadap pembelajaran puisi. Untuk menangani hal tersebut, diperlukan peningkatan kemampuan menulis puisi siswa agar siswa dapat mengetahui tentang bagaimana menulis puisi yang baik.

Melihat kondisi tersebut, peneliti dan guru sebagai kolaborator mendiskusikan cara yang paling mudah dan menyenangkan untuk mulai membuat puisi agar dalam pembelajaran tidak membosankan dan monoton. Pengembangan bahan ajar menulis puisi perlu ditingkatkan, salah satunya dengan menggunakan teknik beriur kata yang dipadukan dengan metode demonstrasi. Metode demonstrasi itu sangat perlu dalam pembelajaran menulis puisi karena dalam menulis puisi diperlukan pula memeragakannnya dalam pembelajaran. Siswa akan lebih mudah menyusun katakata karena sudah ada rangsangan sebelumnya dari huruf awal yang disusun secara vertikal dan membentuk kata karena itulah menulis puisi dengan cara seperti ini akan menjadi pengalaman bermakna bagi siswa. Hal ini akan sangat penting untuk langkah selanjutnya dalam memahami puisi. Selain itu, teknik beriur kata dalam tulisan ini konkritnya adalah siswa dikondisikan untuk berpartisipasi dalam kelompok kecil atau kelompok besar dengan cara mengiur/menyumbang kata berdasarkan ketentuan yang disepakati bersama. Kata-kata yang terkumpul digunakan sebagai bahan dasar pembelajaran menulis puisi. Berdasarkan 
alasan-alasan di atas, penulis mencoba memadukan antara model demonstrasi dan teknik beriur kata diterapkan dalam pengembangan bahan ajar menulis puisi.

Penelitian ini bertujuan menguji pengembangan perencanaan bahan ajar menulis puisi dengan perpaduan model demonstrasi dan teknik beriur kata kelas VIII SMP, menguji kelayakan desain bahan ajar menulis puisi dengan perpaduan model demonstrasi dan teknik beriur kata kelas VIII SMP, menguji keefektifan pengembangan bahan ajar menulis puisi dengan perpaduan model demonstrasi dan teknik beriur kata kelas VIII SMP.

Secara teoretis hasil penelitian ini dapat digunakan mendorong pendidik untuk selalu mengembangkan ilmu pengetahuan yang akan diterapkannya serta menemukan, menghasilkan dan menerapkan pengetahuan yang telah dipelajarinya. Secara praktis hasil penelitian dapat digunakan peserta didik menumbuh kembangkan minat dalam menulis teks puisi, bagi pendidik sebagai salah satu referensi model dan strategi menulis puisi serta meningkatkan profesional pendidik dalam meningkat inovasinya dan bagi sekolah diharapkan mampu mengangkat prestasi sekolah dan dapat bermanfaat sebagai bahan acuan untuk penelitian selanjutnya.

Menurut Uyun (2010, hal. 19) pengembangan adalah proses menerjemahkan spesifikasi desain ke dalam suatu wujud fisik tertentu. Proses penerjemahan spesifikasi desain tersebut meliputi identifikasi masalah perumusan tujuan pembelajaran, pengembangan strategi atau metode pembelajaran dan evaluasi keefektifan, efisien dan kemenarikan pembelajaran. Trianto (2015, hal. 41) mengemukakan bahan ajar adalah segala bentuk bahan yang digunakan oleh guru dalam melaksanakan kegiatan belajar mengajar di kelas. Bahan yang dimaksud bisa berupa bahan tertulis atau bahan tidak tertulis. Bahan ajar merupakan informasi, alat atau teks yang diperlukan oleh guru untuk perencanaan dan penelaahan implementasi pembelajaran. Bahan ajar juga bisa diartikan sebagai seperangkat materi yang disusun secara sistematis, baik tertulis maupun tidak tertulis sehingga tercipta lingkungan atau suasana yang memungkinkan siswa untuk belajar.

Tarigan (2014, hal. 21) menyatakan menulis adalah menurunkan atau melukiskan lambang-lambang grafik yang menggambarkan bahasa yang dipahami oleh seseorang sehingga orang lain dapat membaca lambang-lambang grafik tersebut kalau mereka memahami bahasa dan grafik itu. Artinya, bahwa menulis merupakan suatu kegiatan yang tidak hanya sekadar menggambarkan simbolsimbol grafis secara konkret, tetapi juga menuangkan ide, gagasan, atau pokok pikiran ke dalam bahasa tulis yang berupa rangkaian kalimat yang utuh, lengkap, dan dapat dikomunikasikan kepada orang lain. Jadi, menulis merupakan keterampilan berkomunikasi antar komunikan dalam usaha menyampaikan informasi dengan media bahasa tulis. Berdasarkan uraian tentang tujuan menulis tersebut, dapat disimpulkan bahwa menulis puisi dapat dikategorikan ke dalam tujuan menulis kreatif atau creative purpose. Setiap penulis pasti memiliki gaya penulisan yang berbeda-beda untuk memperlihatkan jati diri dan kreativitasnya. Begitu juga di dalam penulisan sebuah puisi. Perbedaan pemilihan diksi dan gaya yang mereka gunakan itulah yang merupakan proses kreatif dan menimbulkan unsur estetika atau keindahan di dalam puisi.

Waluyo (2015, hal. 1) menyatakan bahwa puisi adalah karya sastra dengan bahasa yang dipadatkan, dipersingkat dan diberi irama dengan bunyi yang padu serta pemilihan kata-kata kias atau imajinatif. Berdasarkan pengertian di atas, dapat disimpulkan bahwa puisi merupakan suatu pemikiran manusia berupa imajinasi yang dituangkan dalam bentuk katakata indah yang menyangkut unsur bunyi bentuk dan 
makna puisi. Kata-kata indah tersebut merupakan wujud ekspresi maupun luapan perasaan penulisnya yang dapat memberikan kesan tersendiri bagi pembacanya.

Unsur-unsur pembangun puisi meliputi bunyi, diksi, bahasa kiasan, citraan, sarana retorika, bentuk visual, dan makna puisi (Wiyatmi, 2009, hal. 57).

1) Bunyi

Menurut Pradopo (2009, hal. 22) pentingnya peranan bunyi dalam kasusasteraan menyebabkan bunyi menjadi salah satu unsur puisi yang paling utama.

2) Diksi

Menurut Sayuti (2002, hal. 143), diksi adalah pemilihan kata yang dilakukan oleh penyair untuk mengekspresikan gagasan dan perasaan-perasaan yang bergejolak dan menggejala dalam dirinya.

3) Bahasa Kiasan

Menurut Sayuti (2002, hal. 195) bahasa kias dalam puisi berfungsi sebagai sarana pengedepanan sesuatu yang berdimensi jamak dalam bentuk yang sesingkatsingkatnya. Sebagai akibat bentuknya yang singkat, bahasa kias juga berfungsi membangkitkan tanggapan pembaca.

4) Citraan

Unsur ciraan merupakan gambarangambaran angan dalam puisi yang ditimbulkan melalui kata-kata (Pradopo, 2009, hal. 79).

5) Sarana Retorika

Nurgiyantoro (2010, hal. 261) mengemukakan sarana retorika (rhetorical devices) merupakan muslihat intelektual, yang dibedakan menjadi beberapa jenis, yaitu: hiperbola, ironi, ambiguitas, paradoks, litotes, dan elipsis.

6) Bentuk Visual

Bentuk visual merupakan salah satu unsur yang paling mudah dikenal. Bentuk ini meliputi penggunaan tipografi dan susunan baris (Nurgiyantoro, 2010, hal. 272).
7) Makna Puisi

Pada umumnya makna puisi baru dapat dipahami setelah seorang pembaca, membaca, memahami arti tiap kata dan kias yang dipakai dalam puisi, serta memperhatikan unsur-unsur puisi lain yang mendukung makna (Nurgiyantoro, 2010, hal. 283).

Model demonstrasi menurut Trianto (2015, hal. 30), cara penyajian bahan pelajaran dengan memeragakan atau mempertunjukkan kepada peserta didik suatu proses, situasi atau benda tertentu yang sedang dipelajari baik sebenarnya atau tiruan yang sering disertai penjelasan lisan. Model demonstrasi adalah model mengajar dimana seorang pendidik atau orang lain yang sengaja meminta peserta didik memperlihatkan kepada seluruh anak di dalam kelas untuk melakukan sesuatu atau mendemonstrasikan sesuatu.

Teknik beriur kata terilhami dari relitas yang ada pada masyarakat, seperti jimpitan dan arisan. Ternyata keduanya itu mampu membangun kebersamaan dan mampu membuat hal yang sulit menjadi mudah. Teknik beriur kata dalam tulisan ini konkritnya adalah siswa dikondisikan untuk berpartisipasi dalam kelompok kecil atau kelompok besar dengan cara mengiur/menyumbang kata berdasarkan ketentuan yang disepakati bersama. Katakata yang terkumpul digunakan sebagai bahan dasar pembelajaran menulis puisi (Trianto, 2015, hal. 24).

Penelitian yang relevan dengan penelitian ini adalah hasil penelitian yang telah dilakukan oleh Adam Rahmat Fauzan (2014) dengan judul penelitiannya Penerapan Metode Sumbang Kata Qurani Dalam Pembelajaran Menulis Puisi. Ajeng Wulandari (2010) dengan judul penelitiannya Peningkatan Kemampuan Menulis Puisi Dengan Penerapan Teknik Rangsang Gambar dan Sumbang Kata Pada Siswa Kelas VII E DI SMP Negeri 1 Jaten. Sandya Dwi Fajri (2010) dengan judul Penelitiannya Peningkatan Kemampuan Menulis Puisi Dengan Menggunakan Teknik 
Akrostik Pada Siswa Kelas VII D Siswa SMP Negeri 5 Bantul.

Perbedaan penelitian ini dengan peneliti-peneliti sebelumnya sebagai berikut. Pertama, penelitian Fauzan (2014) hampir sama dengan teknik beriur kata hanya saja sumbang kata disini dalam bentuk terjemahan ayat Al-Qur'an dalam pembelajaran menulis puisi.

Kedua, penelitian Wulandari (2010) menggunakan bantuan gambar yang menjadi perangsang siswa mendapatkan kata-kata sehingga disebutkan dengan sumbang kata dalam pembelajaran menulis puisi.

Ketiga, penelitian Fajri (2010) penelitian ini hampir sama dengan sumbang kata atau beriur kata hanya saja teknik ini menggunaka daya ingat sebuah materi yang nantinya dipilah menjadi huruh awal, tengah, atau akhir dalam sebuah kata tertentu.

Ketiga penelitian relevan di atas berdasarkan penelitian tindakan kelas, sedangkan penelitian ini pengembangan bahan ajar menulis puisi dengan perpaduan model demonstrasi dan teknik beriur kata.

\section{B. METODE}

Metode penelitian yang digunakan adalah metode penelitian dan pengembangan (R\&D) adalah proses yang digunakan untuk mengembangkan dan memvalidasi produk pendidikan. Penelitian pengembangan merupakan suatu penelitian yang menghasilkan dan menguji ke efektivitas produk baik dari segi proses maupun hasil terkait dengan peningkatan kualitas pendidikan. Produk tersebut dapat berbentuk benda atau perangkat keras, seperti buku, modul, alat bantu pembelajaran di kelas atau laboratorium atau juga perangkat lunak seperti, program komputer, model pembelajaran, dan lain-lain. Langkahlangkah $\mathrm{R} \& \mathrm{D}$, terdiri dari menemukan dan menganalisis sebuah produk, mendesain, mengembangkan produk, mengimplementasikan, dan merevisinya untuk memperbaiki kekurangan yang ditemukan dalam tahap mengajukan pengujian (Sugiyono, 2016, hal. 28). Penelitian pengembangan ini menerapkan sepuluh langkah pengembangan sebagaimana yang dikemukakan Borg \& Gall (melalui Sugiyono 2018, hal. 298) menjelaskan setidaknya ada sepuluh langkah yang dapat ditempuh dalam melaksanakan penelitian pengembangan. Langkah-langkah tersebut ialah sebagai berikut.

1. Penelitian dan pengumpulan informasi (reserch and information collecting), yaitu pengumpulan data awal di lapangan yang dijabarkan/ dipaparkan dalam bentuk studi literatur, observasi lapangan berkenaan dengan pelajaran bahasa indonesia, ketersediaan alat bantu pembelajaran, serta kondisi peserta didik dan juga guru.

2. Perencanaan (planning), yakni menyusun rencana penelitian yang meliputi kemampuan-kemampuan yang diperlukan dalam pelaksanaan penelitian, perumusan tujuan yang akan dicapai dalam penelitian, desain atau langkah-langkah penelitian, dan melakukan evaluasi.

3. Develop prelimenary form and product, yaitu mengembangkan bentuk model awal, mengumpulkan dan menyusun materi ajar, merancang bentuk awal produk yang ingin diciptakan.

4. Uji lapangan awal (prelimenay field testing), yaitu melakukan uji coba strategi secara individual untuk mendapatkan informasi tentang kelemahan dan kekurangan produk yang dikembangkan.

5. Revisi utama produk (main product revision), yaitu memperbaiki hasil uji coba atau perbaikan model awal.

6. Uji coba lapangan utama (main field testing), yaitu uji coba produk dengan memperluas area dan memperbanyak subjek penelitian. 
7. Revisi produk (development revision product), ialah menyempurnakan produk hasil uji lapangan, dilakukan berdasarkan hasil uji coba utama atau perbaikan hasil uji coba produk lebih luas.

8. Uji lapangan operasional (operational field testing), yakni langkah uji validasi terhadap produk yang dihasilkan untuk membuat draf terakhir produk sebelum disebarluaskan untuk diimplementasikan.

9. Revisi produk akhir (final product revision), yaitu penyempurnaan akhir produk berdasarkan uji pelaksanaan lapangan dengan memerhatikan hasil wawancara atau observasi langsung saat pelaksaaan uji coba.

10. Diseminasi dan implementasi produk (dissemination and implementation), yaitu menyebarluaskan dan mengimplementasikan produk yang dihasilkan dari hasil penelitian pengembangan.

\section{PEMBAHASAN}

Hasil penelitian pengembangan bahan ajar menulis puisi dengan perpaduan model demonstrasi dan teknik beriur kata kelas VIII SMP berdasarkan prosedur Borg \& Gall, diketahui bahwa selama ini SMP Muhammadiyah 6 Samarinda menggunakan buku teks pelajaran Bahasa Indonesia sebagai sumber belajar, namun siswa masih kurang memahami materi dalam buku teks tanpa penjelasan dari guru sehingga siswa membutuhkan sumber belajar lain untuk menunjang kegiatan belajar. Siswa cenderung lebih menyukai membaca puisi dari pada harus menulis puisi. Kesulitan yang mereka alami, di antaranya kesulitan mengembangkan ide, memilih kata yang tepat, menentukan irama dan rima yang sesuai. Siswa cenderung mengeluh karena menulis puisi bagi mereka rumit dan sulit. Terkait buku teks pelajaran yang digunakan Berbahasa dan Bersastra Indonesia untuk Siswa Kelas VIII SMP, guru menilai bahwa masih minim penjabaran materi. Materi yang terkandung dalam buku perlu didalami lagi. Penjelasan yang terdapat dalam buku terlalu singkat, jadi guru harus memiliki inisiatif untuk menjelaskan lebih rinci kepada siswa. Selain itu, minimnya bahan ajar yang dimiliki siswa juga menjadi pemicu kurangnya pengetahuan yang dimiliki siswa terutama pada puisi.

Berdasarkan permasalahan tersebut, peneliti melakukan pengembangan bahan ajar menulis puisi dengan perpaduan model demonstrasi dan teknik beriur kata kelas VIII SMP. Pada bahan ajar menulis puisi dengan perpaduan model demonstrasi dan teknik beriur kata kelas VIII SMP yang dikembangkan peneliti menggunakan jenis huruf Magneto (Judul besar), Calibri (Body) (Keterangan pojok kanan pada sampul dan keterangan kelas), Gigib Yudha Pratama (Penulis), dan Arial pada sampul belakang, huruf Cooper Black untuk setiap Bab, huruf Rockwell Extra Bold pada keterangan kolom aktivitas, dan huruf Arial untuk penjabaran materi maupun kegiatan pada bahan ajar. Penggunaan keseluruhan jenis huruf ini bertujuan untuk menvariasi huruf pada bahan ajar dan memudahkan siswa membaca maupun menggunakan yang dikembangkan peneliti. Selain itu, font yang digunakan dimuali dari font 12, 14, 16, 18, dan 26 dengan tujuan menvariasi ukuran huruf agar siswa mengetahui garis besar dan bagian-bagian materi yang dipelajari. Kemudian, penggunaan bahasa yang sederhana dan komunikatif pada bahan ajar yang dikembangkan peneliti mempermudah siswa memahami materi yang terkandung. Selanjutnya, ukuran bahan ajar berpedoman pada ukuran kertas berdasarkan ISO, yaitu 210 x 297 $\mathrm{mm}$. Secara keseluruhan bahan ajar ini memiliki 14 bagian penting, di antaranya Sampul depan Bahan ajar, Kata Pengantar, SK dan KD menulis puisi kelas VIII, Daftar isi, Peta Kedudukan Bahan ajar, Materi, Rangkuman, Tes Formatif I, Tes Formatif II, Glosarium, Kunci Jawaban, 
Daftar Rujukan, Sumber Gambar dan Sampul Belakang.

Kelayakan desain bahan ajar menulis puisi dengan perpaduan model demonstrasi dan teknik beriur kata kelas VIII SMP diperoleh berdasarkan penilaian dan validasi produk dilakukan oleh ahli media dan ahli materi. Penilaian dilakukan oleh para ahli minimal dua kali, hal ini bertujuan untuk mengetahui peningkatan pengembangan produk yang dilakukan peneliti. Selain itu, penilaian juga dilakukan dengan tujuan untuk mengetahui kelayakan produk sebelum dan sesudah direvisi berdasarkan komentar dan saran yang telah diberikan oleh para ahli. Selanjutnya, penilaian akan diteruskan pada guru bahasa Indonesia jika produk yang dikembangkan telah dinilai dan divalidasi serta dinyatakan layak oleh ahli media dan ahli materi.

Berdasarkan data hasil penilaian dan validasi ahli media diketahui bahwa skor rata-rata hasil penilaian dan validasi aspek kelayakan penyajian oleh ahli media pada tahap I sebelum revisi diperoleh nilai 3,9 dengan persentase $78,2 \%$. Hal ini berarti ahli media menyatakan bahwa bahan ajar menulis puisi dengan perpaduan model demonstrasi dan teknik beriur kata dari aspek kelayakan penyajian layak sebagai bahan ajar mandiri untuk siswa Kelas VIII SMP pada tahap I sebelum revisi. Pada tahap II setelah revisi terjadi peningkatan yaitu skor rata-rata hasil penilaian dan validasi aspek kelayakan penyajian oleh ahli media diperoleh nilai 4,8 dengan persentase 96,4\%. Hal ini berarti ahli media menyatakan bahwa bahan ajar menulis puisi dengan perpaduan model demonstrasi dan teknik beriur kata dari aspek kelayakan penyajian sangat layak sebagai bahan ajar mandiri untuk siswa Kelas VIII SMP pada tahap II setelah revisi.

Pada aspek kelayakan kegrafikan, diketahui bahwa skor rata-rata hasil penilaian dan validasi aspek kelayakan kegrafikan oleh ahli media pada tahap I sebelum revisi diperoleh nilai 3,5 dengan persentase $70 \%$. Hal ini berarti ahli media menyatakan bahwa bahan ajar menulis puisi dengan perpaduan model demonstrasi dan teknik beriur kata dari aspek kelayakan kegrafikan layak sebagai bahan ajar mandiri untuk siswa Kelas VIII SMP pada tahap I sebelum revisi. Pada tahap II setelah revisi terjadi peningkatan yaitu skor rata-rata hasil penilaian dan validasi aspek kegrafikan penyajian oleh ahli media diperoleh nilai 5 dengan persentase $100 \%$. Hal ini berarti ahli media menyatakan bahwa bahan ajar menulis puisi dengan perpaduan model demonstrasi dan teknik beriur kata dari aspek kelayakan kegrafikan sangat layak sebagai bahan ajar mandiri untuk siswa Kelas VIII SMP pada tahap II setelah revisi.

Peningkatan skor rata-rata hasil penilaian dan validasi aspek kelayakan penyajian dan aspek kelayakan kegrafikan oleh ahli media dari layak menjadi sangat layak terjadi berdasarkan revisi yang telah dilakukan peneliti terhadap bahan ajar yang dikembangkan. Adapun aspek yang direvisi, yaitu gambar yang tidak bervariasi, kejelasan fungsi suatu gambar, font tulisan yang tidak terbaca, dan ilustrasi atau gambar yang tidak berwarna.

Revisi produk oleh ahli media dilakukan sebanyak satu kali. hal ini dilakukan berdasarkan perbaikan yang perlu dilakukan atas saran dan masukan dari ahli media. Berikut masukan perbaikan dan komentar dari ahli media terhadap bahan ajar yang telah dikembangkan peneliti. Setelah dilakukan penilaian dan validasi oleh ahli media, terdapat beberapa masukan dan komentar pada bahan ajar yang peneliti kembangkan. Adapun perbaikan yang harus dilakukan, yakni terdapat gambar yang tidak jelas fungsinya. Hal ini akan menyebabkan kebingungan bagi siswa. Saran dari ahli media, jika tidak terdapat kejelasan suatu fungsi pada bahan ajar, lebih layak diilangkan saja atau diganti 
dengan ilustrasi atau gambar yang menunjukan suatu kegiatan. Ada baiknya gambar diletakan pada keterangan aktvitas yang akan dilakukan. Setelah direvisi gambar yang tidak memiliki fungsi pada produk yang dikembangkan ditiadakan. Pada aspek kegrafikan, perbaikan atau revisi yang harus dilakukan peneliti, yaitu ukuran gambar yang harus diperbesar atau diperbaiki tata letaknya. Hal ini bertujuan agar kalimat atau kata yang terdapat pada gambar. Selain itu, ahli media juga menyarankan untuk merevisi gambar pada tiap judul yang sama agar bervariasi. Dianjurkan juga, gambar atau ilustrasi hendaknya berwarna. hal ini bertujuan untuk meningkatkan motivasi dan semangat siswa menggunakan bahan ajar.

Hasil penilaian oleh ahli materi diketahui bahwa skor rata-rata hasil penilaian dan validasi aspek kelayakan isi oleh ahli materi pada tahap I sebelum revisi diperoleh nilai 3,16 dengan persentase 63,3\%. Hal ini berarti ahli materi menyatakan bahwa bahan ajar menulis puisi dengan perpaduan model demonstrasi dan teknik beriur kata dari aspek kelayakan isi layak sebagai bahan ajar mandiri untuk siswa Kelas VIII SMP pada tahap I sebelum revisi. Pada tahap II setelah revisi, skor rata-rata hasil penilaian dan validasi aspek kelayakan isi oleh ahli materi diperoleh nilai 4,5 dengan persentase $90 \%$. Hal ini berarti ahli materi menyatakan bahwa bahan ajar menulis puisi dengan perpaduan model demonstrasi dan teknik beriur kata dari aspek kelayakan isi sangat layak sebagai bahan ajar mandiri untuk siswa Kelas VIII SMP pada tahap II setelah revisi. Kemudia tahap III setelah revisi, skor rata-rata hasil penilaian dan validasi aspek kelayakan isi oleh ahli materi diperoleh nilai 4,66 dengan persentase $93,3 \%$. Hal ini berarti ahli materi menyatakan bahwa bahan ajar menulis puisi dengan perpaduan model demonstrasi dan teknik beriur kata dari aspek kelayakan isi sangat layak sebagai bahan ajar mandiri untuk siswa Kelas VIII SMP pada tahap III setelah revisi.

Pada aspek kelayakan kebahasaan, diketahui bahwa skor rata-rata hasil penilaian dan validasi aspek kelayakan kebahasaan oleh ahli materi pada tahap I sebelum revisi diperoleh nilai 3,4 dengan persentase $68 \%$. Hal ini berarti ahli materi menyatakan bahwa bahan ajar menulis puisi dengan perpaduan model demonstrasi dan teknik beriur kata dari aspek kelayakan kebahsaan layak sebagai bahan ajar mandiri untuk siswa Kelas VIII SMP pada tahap I sebelum revisi. Pada tahap II setelah revisi, skor rata-rata hasil penilaian dan validasi aspek kelayakan kebahasaan oleh ahli materi diperoleh nilai 4 dengan persentase $80 \%$. Hal ini berarti ahli materi menyatakan bahwa bahan ajar menulis puisi dengan perpaduan model demonstrasi dan teknik beriur kata dari aspek kelayakan kebahasaan layak sebagai bahan ajar mandiri untuk siswa Kelas VIII SMP pada tahap II setelah revisi. Kemudian tahap III setelah revisi, skor rata-rata hasil penilaian dan validasi aspek kelayakan kebahasaan oleh ahli materi diperoleh nilai 4,6 dengan persentase $92 \%$. Hal ini berarti ahli materi menyatakan bahwa bahan ajar menulis puisi dengan perpaduan model demonstrasi dan teknik beriur kata dari aspek kelayakan kebahasaan sangat layak sebagai bahan ajar mandiri untuk siswa Kelas VIII SMP pada tahap III setelah revisi.

Pada aspek penerapan model demonstrasi dan teknik beriur kata, diketahui bahwa penilaian dan validasi aspek penerapan model demonstrasi dan teknik beriur kata oleh ahli materi baru dilakukan pada tahap II setelah revisi, dimana skor rata-rata hasil penilaian dan validasi aspek penerapan model demonstrasi dan teknik beriur kata oleh ahli materi diperoleh nilai 3,66 dengan persentase $73,3 \%$. Hal ini berarti ahli materi menyatakan bahwa bahan ajar menulis puisi dengan perpaduan model demonstrasi dan teknik beriur kata dari 
aspek penerapan model demonstrasi dan teknik beriur kata layak sebagai bahan ajar mandiri untuk siswa Kelas VIII SMP pada tahap II setelah revisi. Kemudian tahap III setelah revisi, skor rata-rata hasil penilaian dan validasi aspek penerapan model demonstrasi dan teknik beriur kata oleh ahli materi diperoleh nilai 4,66 dengan persentase 93,3\%. Hal ini berarti ahli materi menyatakan bahwa bahan ajar menulis puisi dengan perpaduan model demonstrasi dan teknik beriur kata dari aspek penerapan model demonstrasi dan teknik beriur kata sangat layak sebagai bahan ajar mandiri untuk siswa Kelas VIII SMP pada tahap III setelah revisi.

Revisi produk oleh ahli materi dilakukan sebanyak dua kali dengan revisi akhir sebagai penyempurnaan. Saat dilakukan penilaian dan validasi, ahli materi memberikan masukan perbaikan dan komentar pada bahan ajar yang dikembangkan peneliti. Berikut masukan perbaikan dan komentar oleh ahli materi terhadap aspek isi dan aspek bahasa pada bahan ajar. Pada aspek isi, ahli materi memberikan masukan perbaikan mengenai kurangnya kegiatan yang mencerminkan isi sesuai dengan model demonstrasi dan teknik beriur kata. Oleh sebab itu, perlu adanya penambahan kegiatan pada tes akhir bahan ajar. Pada aspek kebahasaan, bagian harus diperbaiki yaitu bahasa baku. Secara keseluruhan bahasa bahan ajar haruslah menggunakan bahasa yanng baku dan komunikatif. Saran dari ahli materi, hendaknya memperhatikan bahasa komunikatif yang baku.

Data hasil penilaian oleh guru bahasa Indonesia diketahui bahwa skor rata-rata hasil penilaian dan validasi tiap aspek oleh guru Bahasa Indonesia diperoleh nilai 3,75 dengan persentase $75 \%$. Hal ini berarti guru Bahasa Indonesia menyatakan bahwa bahan ajar menulis puisi dengan perpaduan model demonstrasi dan teknik beriur kata berkategori layak sebagai bahan ajar mandiri untuk siswa Kelas VIII SMP. Hasil yang diperoleh beradasarkan respon siswa terhadap bahan ajar, bahwasannya bahan ajar 1 telah tepat digunakan bagi mereka. Mereka menyatakan bahwa bahan ajar menulis puisi dengan perpaduan model demonstrasi dan teknik beriur kata kelas VIII SMP mudah dipahami dan dipelajari secara mandiri. Selain itu penyempurnaan produk berasal dari saran perbaikan dan komentar dari para ahli, guru, dan respon siswa. Dapat disimpulkan bahwa bahan ajar yang dikembangkan oleh peneliti telah layak digunakan oleh siswa kelas VIII SMP.

Hasil uji coba terhadap siswa kelas VIII SMP ini merupakan data terakhir yang diperoleh setelah penilaian dilakukan oleh ahli media, ahli materi dan guru bahasa Indonesia. Uji coba bahan ajar yang dikembangkan peneliti hanya sebatas pada tanggapan atau respon siswa kelas VIII SMP yang telah ditentukan oleh guru bahasa Indonesia. Aspek kelayakan penyajian dengan indikator penilaian meliputi penyajian materi berpusat pada siswa, terdapat contoh dan ilustrasi dalam bahan ajar yang mudah siswa pahami, bahan ajar yang disediakan sesuai dengan tingkat pemahaman siswa, penyajian materi pada bahan ajar mendorong motivasi dan semangat siswa untuk belajar dan tujuan pembelajaran telah disampaikan pada setiap bab diperoleh skor rata-rata sebesar 4,6 dengan persentase $92 \%$ yang berarti bahan ajar menulis puisi dengan perpaduan model demonstrasi dan teknik beriur kata kelas VIII SMP berdasarkan aspek kelayakan penyajian sangat layak menurut respon siswa kelas VIII SMP.

Aspek kelayakan kegrafikan dengan indikator penilaian meliputi desain sampul kreatif dan menarik, desain isi bahan ajar menarik dan kreatif, huruf yang digunakan sesuai dan mudah dibaca dan ilustrasi menarik minat saya untuk menulis puisi diperoleh skor rata-rata sebesar 4,7 dengan persentase $94 \%$ yang berarti bahan ajar menulis puisi dengan perpaduan 
model demonstrasi dan teknik beriur kata kelas VIII SMP berdasarkan aspek kelayakan kegrafikan sangat layak menurut respon siswa kelas VIII SMP.

Aspek kelayakan isi dengan indikator penilaian meliputi materi dalam bahan ajar runtut dan tidak membingungkan siswa, materi yang terdapat dalam bahan ajar memotivasi siswa untuk menulis puisi lebih lanjut, materi yang disampaikan menambah pengetahuan dan mempermudah siswa menulis puisi, penyampaian materi memudahkan siswa memahami puisi dan setiap penugasan mudah siswa pahami diperoleh skor ratarata sebesar 4,56 dengan persentase $91,2 \%$ yang berarti bahan ajar menulis puisi dengan perpaduan model demonstrasi dan teknik beriur kata kelas VIII SMP berdasarkan aspek kelayakan isi sangat layak menurut respon siswa kelas VIII SMP.

Aspek kelayakan bahasa dengan indikator penilaian meliputi bahasa yang digunakan mudah siswa pahami, bahasa yang digunakan komunikatif dan bahasa yang digunakan sederhana dan tidak sulit siswa pahami diperoleh skor rata-rata sebesar 4,46 dengan persentase 89,2\% yang berarti bahan ajar menulis puisi dengan perpaduan model demonstrasi dan teknik beriur kata kelas VIII SMP berdasarkan aspek kelayakan bahasa sangat layak menurut respon siswa kelas VIII SMP.

Aspek kelayakan penerapan model demonstrasi dan teknik beriur kata dengan indikator penilaian meliputi materi memudahkan saya menulis berdasarkan pengalaman, siswa dapat menerapkan langkah-langkah yang disediakan pada bahan ajar, dan materi menulis puisi dalam bahan ajar mudah saya pahami diperoleh skor rata-rata sebesar 4,66 dengan persentase $93,2 \%$ yang berarti bahan ajar menulis puisi dengan perpaduan model demonstrasi dan teknik beriur kata kelas VIII SMP berdasarkan aspek kelayakan penerapan model demonstrasi dan teknik beriur kata sangat layak menurut respon siswa kelas VIII SMP. Saran dan pendapat dari siswa, menurut mereka bahan ajar ini sudah sangat layak digunakan siswa SMP. Selain itu, sebaiknya bahasa yang digunakan harus diperhatikan dan dipermudah lagi agar tidak ada kata-kata yang sulit dipahami. Sehingga, mempelajari puisi akan lebih mudah lagi.

\section{PENUTUP}

Pengembangan perencanaan bahan ajar menulis puisi dengan perpaduan model demonstrasi dan teknik beriur kata kelas VIII SMP memiliki 14 bagian penting, di antaranya Sampul depan Bahan ajar, Kata Pengantar, SK dan KD menulis puisi kelas VIII, Daftar isi, Peta Kedudukan Bahan ajar, Materi, Rangkuman, Tes Formatif I, Tes Formatif II, Glosarium, Kunci Jawaban, Daftar Rujukan, Sumber Gambar dan Sampul Belakang. Skor rata-rata penilaian dan validasi oleh ahli media, ahli materi, dan guru bahasa Indonesia diperoleh nilai 4,43. Nilai ini berarti bahan ajar menulis puisi dengan perpaduan model demonstrasi dan teknik beriur kata kelas VIII SMP sangat layak digunakan sebagai bahan ajar mandiri untuk siswa Kelas VIII SMP. Hasil uji coba penilaian dan validasi tiap aspek diperoleh skor rata-rata sebesar 4,58, nilai ini berarti bahan ajar menulis puisi dengan perpaduan model demonstrasi dan teknik beriur kata kelas VIII SMP sangat efektif menurut respon siswa kelas VIII SMP.

\section{DAFTAR PUSTAKA}

Adam, R. F. (2014). Penerapan Metode Sumbang Kata Qurani dalam Pembelajaran Menulis Puisi. Tesis. Universitas Pendidikan Indonesia. http://repository.upi.edu/16381/

Agustina, Y. (2017). Pengembangan Pelaksanaan Pembelajaran Menulis Teks Eksposisi Menggunakan Model Sugesti Imajinasi dengan Audio- 
Visual Siswa Kelas X MM SMKN 15

Samarinda. LOA: Jurnal Ketatabahasaan dan Kesusastraan, 13(1), 57-62.

https://ojs.badanbahasa.kemdikbud. go.id/jurnal/index.php/loa/article/v iew $/ 1652$

Ajeng, W. (2010). Peningkatan Kemampuan Menulis Puisi dengan Penerapan Teknik Rangsang Gambar dan Sumbang Kata pada Siswa Kelas VII E DI SMP Negeri 1 Jaten. Tesis. Universitas Muhammadiyah Surakarta. http://eprints.ums.ac.id/8472/

Aminuddin. (2002). Pengantar Apresiasi Sastra. Bandung: Sinar Baru Algesindo.

Eko, P. W. (2012). Teknik Penyusunan Instrumen Penelitian. Yogyakarta: Pustaka Pelajar.

Endaswara, S. (2013). Metode dan Teori Pengajaran Sastra. Yogyakarta: Buana Pustaka.

Fajri, S. D. (2010). Peningkatan Kemampuan Menulis Puisi Dengan Mengunakan Teknik Akrostik Pada Siswa Kelas VII D SMP Negeri 5 Banguntapan Bantul. Bantul: Universitas Negeri Yogyakarta. Skripsi. Universitas Negeri Yogyakarta.

https:/ / eprints.uny.ac.id/20692/1/S andya $\% 20$ Dwi $\% 20 F a j r i \% 201020124$ 1005.pdf

Hamalik, O. (2007). Manajemen Pengembangan Kurikulum. Bandung: Remaja Rosda Karya.

Hamiyah, N. \& Jauhar, M. (2014). Strategi Belajar-Mengajar di Kelas. Jakarta: Prestasi Pustaka.

Hartoko, D. \& Rahmanto, R. (1986). Pemandu di Dunia Sastra. Yogyakarta: Kanisius.

Jamilah, N. (2020). Pengembangan Bahan Ajar Interaktif 'POST' dalam Pembelajaran Apresiasi Puisi untuk Siswa Kelas X SMA. Diglosia: Jurnal Kajian Bahasa, Sastra, dan
Pengajarannya, 3(1), 14-23. https://doi.org/10.30872/diglosia.v $3 \mathrm{i} 1.28$

Keraf, G. (2006). Argumentasi dan narasi. Jakarta: Gramedia Pustaka.

Koentjaningrat. (1982). Pengantar Ilmu Antropologi. Jakarta: Aksara Baru.

Kosasih, E. (2013). Kreatif Berbahasa Indonesia. Jakarta: Erlangga.

Nurgiyantoro, B. (2010). Teori Pengkajian Fiksi. Yogyakarta: GadjahMada University Press.

Pradopo, R. D. (2009). Beberapa Teori Sastra, Metode, Kritik, dan Penerapannya. Yogyakarta: Pustaka Belajar.

Rajja. (2020). Pengembangan Bahan Ajar Menulis Teks Cerpen dengan Metode Cerpen-gram untuk Siswa Kelas IX di Kecamatan Muara Wahau. Diglosia: Jurnal Kajian Bahasa, Sastra, Dan Pengajarannya, 3(1), 24-32. https://doi.org/10.30872/diglosia.v $3 i 1.26$

Rokhmansyah, A. (2014). Studi dan Pengkajian Sastra. Yogyakarta: Graha Ilmu.

Rusman. (2014). Model-Model Pembelajaran. Jakarta: Raja Grafindo Persada.

Sandya. D. F. (2010). Peningkatan Kemampuan Menulis Puisi dengan Menggunakan Teknik Akrostik pada Siswa Kelas VII D Siswa SMP Negeri 5 Bantul. Tesis. Universitas Negeri Yogyakarta.

https://eprints.uny.ac.id/20692/

Sari, L. K. (2019). Pengembangan Pembelajaran Menulis Teks Ceramah dengan Model Problem Based Learning Dipadukan Media Gambar pada Siswa Kelas XI SMA. Diglosia: Jurnal Kajian Babasa, Sastra, dan Pengajarannya, 2(1), 59-72. https://doi.org/10.30872/diglosia.v 2i1.18

Sayuti, S. A. (2002). Menuju Pengajaran Bahasa dan Sastra yang Bermakna. Kongres Bahasa Indonesia VIII. Jakarta: Pusat Bahasa. 
Semi, A. (2007). Dasar-Dasar Keterampilan Menulis. Bandung: Angkasa.

Sugiyono. (2016). Metode Penelitian of Pengembangan (Research and Development). Jakarta: Alfabeta.

Sutama, I M. (2016). Pembelajaran Menulis.Yogyakarta: Pustaka Pelajar.

Syaodih, S. (2006). Metode Penelitian Pendidikan. Bandung: Remaja Rosda Karya.

Tarigan, H. G. (2008). Menulis. Bandung: Angkasa.

Tarigan, H. G. (2013). Berbicara sebagai Suatu Keterampilan Berbahasa. Bandung: Angkasa.

Tilaar, H. A. R. (2011). Kekuasaan dan Pendidikan: Kajian Menejemen
Pendidikan Nasional dalam Pusaran Kekuasaan. Jakarta: Rineka Cipta.

Trianto. (2015). Mendesain Model Pembelajaran Inovatif, Progresif, dan Kontekstual. Jakarta: Prenadamedia Group.

Van Luxemburg, J., Bal, M., \& Weststeijn, W. G. (2005). Pengantar Ilmu Sastra. Jakarta: Gramedia Pustaka Utama.

Waluyo, B. (2015). Bahasaku Bahasa Indonesia, Untuk Kelas IX SMP dan MTs. Solo: Platinum.

Wibowo, H. (2018). Model dan Teknik Pembelajaran Bahasa Indonesia. Depok: Puri Cipta Media.

Wiyatmi. (2009). Pengantar Kajian Sastra. Yogjakarta: Pustaka Pelajar. 